\title{
Health Risk Assessment of Organophosphate Residues in Rice and Vegetables in Banggai, Central Sulawesi, Indonesia
}

\author{
Budi Hartono*, Mufidatul Husna \\ Department of Environmental Health, Public Health Faculity, Universitas Indonesia, Depok, Indonesia
}

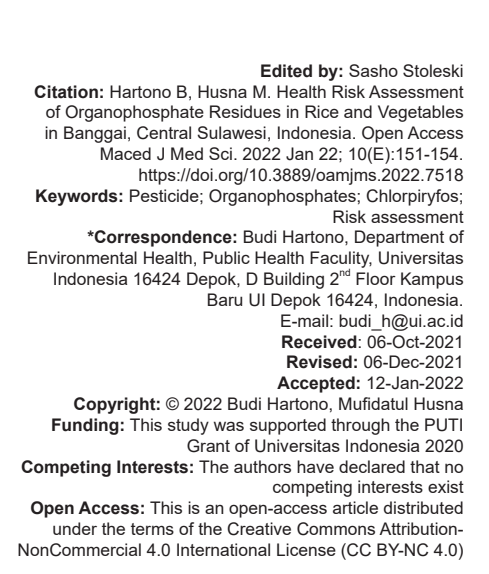

Abstract

BACKGROUND: Agriculture is the largest sector in Indonesia, while farmers commonly use pesticides such as organophosphate to protect farmlands from pests and diseases. However, the residues left on plants due to its application lead to various acute and chronic health problems

AIM: This study aimed to evaluate the risk quotient $(R Q)$ in populations due to organophosphate exposure in food samples.

MATERIALS AND METHODS: Environmental health risk assessment was carried out involving 160 respondents, while four vegetable samples were tested for pesticide residue using gas chromatography. Furthermore, the characteristics of the respondents were collected using a questionnaire to calculate the intake and $R Q$.

RESULTS: The results showed that the $R Q$ in the population was $<1$, while the calculation of $R Q$ for individuals showed that a value $>1$ was 49 respondents, 27 respondents have an $R Q$ of 1.1-1.5, 17 respondents have an $R Q$ of $1.6-2.0$, and 11 respondents have an $R Q>2$.

CONCLUSION: Based on the result, the population is not at risk from its exposure to organophosphate residues in vegetables; however, individual exposure needs a profound attention to prevent the risk associated.

\section{Introduction}

Agriculture is the leading economic sector in Indonesia, while farmers commonly use pesticides such as organophosphate as an intervention against pests and diseases on farmlands. Furthermore, the global production of pesticides increased by $11 \%$ annually between the 1950s and 2000 from 0.2 million tons to over 5 million tons [1], and in 2012, an average of 3.8 million tons were applied to farmlands [2]. Indonesia also experienced a $10 \%$ increase in pesticide use from 2006 to 2010, and the number of registered pesticide products increased from 2605 in 2010 to 3207 in 2016.

In addition, a person comes in contact with pesticides through the skin, inhalation, and ingestion, but high doses of organophosphates are highly toxic inside and outside the workplace [3], [4]. The misuse of pesticides in agriculture [5], especially in vegetable farming, is harmful to humans [6]. Several studies have revealed its association with various health problems such as cardiovascular diseases [7], immunotoxicity, male reproductive disorders [7], nervous system disorders [8], [9], endocrine system disorders, birth defects [10], dementia, and neurological disorders in children [11]. Apart from using pesticides to improve food safety, the intensive and widespread use also leads to soil pollution, which increases environmental and health risks [12].

Pesticides are used to protect farm produce such as fruits and vegetables that are susceptible to insect attacks and diseases; consequently, they become a major source of pesticide residues, raising food safety concerns globally [13]. Meanwhile, rice is one of the main foods in Indonesia and it is very susceptible to pest attacks during planting and storage. This has led to the use of pesticides by farmers, but there have been cases of careless and inappropriate use, which leads to contamination of food crops.

Analyzing the pesticide residues in food are a means of monitoring the risk due to its presence in food consumed daily; moreover, further studies are needed to analyze the health risks that arise in the community. Therefore, this study aims to determine the risk posed on the community's health due to pesticide residues in vegetables consumed. 


\section{Materials and Methods}

\section{Subject selection}

This research was conducted in Purwo Agung Village, Masama District, Banggai Regency, Central Sulawesi Province in November 2020. Samples of the subject in this study were 160 people with inclusion criteria, (1) aged 20-65 years, (2) living in Purwo Agung Village, Masama District, Banggai Regency for a minimum of 7 years continuously, for at least 350 days a year, (3) consuming rice and vegetables grown in Purwo Agung Village, and (4) Willing to be respondents in this study.

\section{Sample selection and laboratory analysis for organophosphates}

The types of vegetable used for this study were determined through interviews with respondents using a questionnaire. Based on the result, three types of vegetables are commonly consumed by the community, which include spinach, kale, and long beans. The criteria for the sample are: (1) Vegetables that were mostly consumed by the community based on the results of interviews, (2) vegetables that looked fresh, and (3) harvest from the people of Purwo Agung Village. Subsequently, rice and vegetable samples were randomly obtained from sellers and gardens with a total weight of approximately $2 \mathrm{~kg}$. They were wrapped with aluminum foil, covered with plastic wrap, and placed in an icebox to keep it fresh. Finally, the samples were sent to Balai Proteksi Tanaman Pangan dan Holtikultura (BPTPH) in South Sulawesi to determine the level of pesticides using gas chromatography with an Agilent 7890.

\section{Health risk assessment (HRA) of organophosphates}

This study used HRA. Basically, HRA is divided into four steps: (a) Hazard identification, (b) doseresponse analysis, (c) exposure assessment, and (d) risk characterization. The following equation can be used to determine the intake and the risk quotient $(R Q)$ [14].

$$
\begin{aligned}
& I=\frac{C \times R \times f_{E} \times D_{t}}{W_{b} \times t_{\text {avg }}} \\
& R Q=\frac{I}{R f D}
\end{aligned}
$$

\section{Results}

\section{Analysis of organophosphate residues}

The examination was carried out on three samples of vegetables and one sample of rice taken from
Table 1: Concentration of chlorpyrifos on rice, spinach, kale, and long beans vegetables at horticulture farmer

\begin{tabular}{lllll}
\hline No & Sample & $\begin{array}{l}\text { Concentration of detected } \\
\text { chlorpyrifos }(\mathrm{mg} / \mathrm{kg})\end{array}$ & $\begin{array}{l}\text { MRL } \\
(\mathrm{mg} / \mathrm{kg})\end{array}$ & Weight \\
\hline 1 & Rice & ND & 0.5 & $1 \mathrm{~kg}$ \\
2 & Spinach & ND & 1 & $1 \mathrm{~kg}$ \\
3 & Kale & 0.0082 & 1 & $1 \mathrm{~kg}$ \\
4 & Long beans & ND & 1 & $1 \mathrm{~kg}$ \\
\hline \multicolumn{7}{l}{ Maximum residue limit established by the Indonesian national standard 2015 [15], ND: Not detected. }
\end{tabular}

community plantations. Of the four samples analyzed, only sample of the kale vegetable type was residuedetected with the active ingredient of chlorpyrifos, which was $0.0082 \mathrm{mg} / \mathrm{kg}$. While in other samples, pesticide residues were not detected (Tables 1 and 2).

Table 2: Concentration of other residues on rice, spinach, kale, and long beans vegetables at horticulture farmer

\begin{tabular}{lllll}
\hline No & Sample & Diazion & Profenofos & Metidation \\
\hline 1 & Rice & ND & ND & ND \\
2 & Spinach & ND & ND & ND \\
3 & Kale & ND & ND & ND \\
4 & Long Beans & ND & ND & ND \\
\hline ND: Not detected. & & &
\end{tabular}

\section{$R Q$}

$R Q$ is calculated based on the duration of the present exposure (real-time), predictions of 7 years, 10 years, and 20 years (Table 3 ). Using the value or data after the Kolmogorov-Smirnov normality test, that is, if $p>0.05$, then the data are normally distributed but some data are not normally distributed so that the median value is used to calculate the risk level. The health risk to the population in real-time exposure is 0.7 , the 7 years was 0.17 , the 10 years was 0.24 , and the 20 years was 0.5 (Table 3 ).

\begin{tabular}{|c|c|c|c|c|c|c|c|c|c|}
\hline \multirow{2}{*}{$\begin{array}{l}\text { Active } \\
\text { ingredients }\end{array}$} & \multirow[t]{2}{*}{$\mathrm{C}(\mathrm{mg} / \mathrm{g})$} & \multicolumn{4}{|c|}{ Intake $(\mathrm{mg} / \mathrm{kg} / \mathrm{h})$} & \multicolumn{4}{|l|}{$R Q$} \\
\hline & & Real-time & $7^{\text {th }}$ & $10^{\text {th }}$ & $20^{\text {th }}$ & Real-time & $7^{\text {th }}$ & $10^{\text {th }}$ & $20^{\text {th }}$ \\
\hline Klorpirifos & $8.2 \times 10^{-3}$ & $3.5 \mathrm{E}-3$ & $8.6 \mathrm{E}-3$ & $2.4 \mathrm{E}-3$ & $4.9 \mathrm{E}-3$ & 0.7 & 0.17 & 0.24 & 0.5 \\
\hline
\end{tabular}

Table 3: Risk quotient of chlorpyrifos in population

Overall, the population risk level has an $R Q$ value $<1$. It can be said that exposure to pesticide residues with the active ingredient chlorpyrifos with a concentration of 0.0082 is safe for consumption by people weighing $66 \mathrm{~kg}$ with an exposure frequency of 52 days/year and an exposure duration of 30 years. It is caused by $R Q$ value $<1$. The value of the risk level $(R Q)$ in the population will be different for each individual, the characteristics of the respondents will affect the risk level $(R Q)$ received by each individual (Table 4).

Table 4: Characteristics of chlorpyrifos exposure

\begin{tabular}{llll}
\hline Individual characteristics & mean \pm SD & Median & Range \\
\hline Body Weight $\left(\mathrm{W}_{\mathrm{b}}\right)$ & $66.1 \pm 10.403$ & 65 & $41-95$ \\
$\quad$ Men & $63.71 \pm 11.081$ & 63 & $41-85$ \\
$\quad$ Women & $61.03 \pm 12.443$ & 60 & $54-98$ \\
Ingestion Rate of Food $(\mathrm{R})$ & $180.38 \pm 29.84$ & 200 & \\
$\quad$ Men & $173 \pm 37.992$ & 200 & $0-200$ \\
$\quad$ Women & $181 \pm 34.357$ & 200 & \\
Exposure Frequency $\left(\mathrm{f}_{\mathrm{E}}\right)$ & $65.32 \pm 26.882$ & 52 & $0-156$ \\
$\quad$ Men & $63 \pm 25.647$ & 52 & \\
Women & $66.33 \pm 27.718$ & 52 & \\
Exposure Duration $\left(\mathrm{D}_{\mathrm{t}}\right)$ & $31.32 \pm 12.072$ & 30 & $7-58$ \\
$\quad$ Men & $31 \pm 12.461$ & 30 & \\
Women & $31.46 \pm 11.928$ & 30 & \\
\hline SD: Standard deviation. & & &
\end{tabular}


Respondents with $R Q<1$ or included in the safe category from the risk of non-carcinogenic diseases were 105 people and respondents with $R Q$ $>1$ or included in the risk category were 55 people. For the risk of carcinogens, the most of the respondents have a value of $R Q<1$ that is as many as 152 people or it can be said that $95 \%$ of the respondents belong to the safe group against the risk of health problems from the effects of carcinogens and as many as eight people or $5 \%$ of respondents have $R Q$ value $>1$ which belongs to the group with risk of health problems from the effects of carcinogens (Figure 1), with health problems experienced in the past few months such as respiratory problems, hypertension, chronic cough, diabetes, and nervous system disorders.

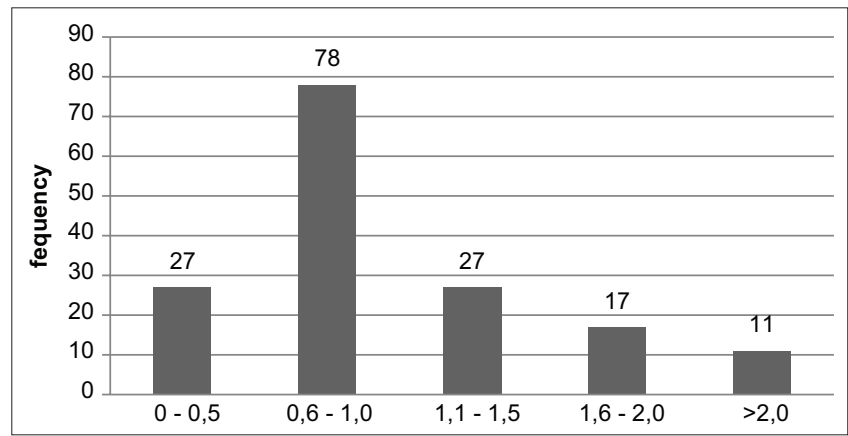

Figure 1: Individual risk quotient of non-carcinogenic effect

\section{Discussion}

Globally, organophosphates are one of the most widely used pesticides because they have more biodegradable characteristics and ease of decomposition in the environment than others [16]. Furthermore, they protect plants from pests by inhibiting the activity of acetyl cholinesterase (AChE) in insects when sprayed on plants, consequently, some residues are often found in soil, water, fruit, and vegetables [17]. They also affect humans directly or indirectly through various means such as contaminated food and through the skin, mouth, eyes, and respiratory system. Moreover, organophosphates are toxic chemical compounds that have been used globally to eradicate pests and the clinical manifestations vary among victims of its poisoning depending on the compound, amount, route, length of exposure, age, and health status [17].

Based on the analysis results on the four samples, comprising rice, spinach, kale, and long beans, only kale indicated the presence of pesticide residue with a concentration of $0.0082 \mathrm{mg} / \mathrm{kg}$ due to the degradation or disappearance of residue in other samples [18]. However, it was still classified as safe as the concentration did not exceed the standard of $1 \mathrm{mg} / \mathrm{kg}$ for vegetables set by the Peraturan Menteri Pertanian
Republik Indonesia Tahun 2015 [15]. Although pesticide residues in vegetables are below the BMR (Minimum Residue Limit), serious health problems still result from continuous exposure through ingestion or other means.

The risk calculation of non-carcinogens in the population showed a result of $0.0036 \mathrm{mg} / \mathrm{kg}$-day. In contrast, the risk level for individuals showed that 49 respondents have an $R Q$ value $>1$ with a difference in the intake value of each individual due to different values of the variables used during calculation. The estimated risk level within 7 years, 10 years, and 20 years also showed an $R Q$ value $<1$; however, individual exposure needs to be prevented to reduce the risk associated with it.

The risk analysis aims to predict the level of risk posed on the community's health after several complaints related to the long-term effects of pesticides, including headaches in 66 people, memory loss in 92, prolonged cough in four, and 11 had respiratory problems. This is consistent with Raschke and Burger, 1996, in South Africa, which observed that pesticide exposure to water, air, and food contributes approximately $15 \%$ of the health problems experienced by the population.

Prolonged oral exposure to chlorpyrifos leads to respiratory distress due to cholinesterase inhibition, while the high levels of organophosphate exposure lead to the inhibition of the AChE. Furthermore, biochemical studies show that AChE inhibition in the brain triggers oxidative stress and neurodegenerative diseases [19]; this is in line with this study which observed that $57.5 \%$ of the respondents experienced memory loss. At the same time, respiratory distress was also observed in adults after oral exposure to approximately $300 \mathrm{mg} /$ $\mathrm{kg}$ of chlorpyrifos [20]. Since the risk analysis method did not examine the causes of exposure to risk agents, further studies are advised to analyze the impact of pesticides on community health.

\section{Conclusion}

Based on the result, the risk quotient of the population is $<1$, indicating that the population is safe from health risks that result from the presence of pesticides residues in food. Moreover, the residues were only detected in the kale samples with a concentration of $0.0082 \mathrm{mg} / \mathrm{kg}$, and the active ingredient detected was chlorpyrifos. Although the detected levels are still below the established MRL, prolonged exposure leads to various health problems. Therefore, there is a need to supervise and monitor the use or application of pesticides, and further study that measures the biomarkers of pesticide exposure are recommended. 


\section{References}

1. Carvalho FP. Pesticides, environment, and food safety. Food Energy Secur. 2017;6(2):48-60.

2. FAO, Agricultural Pollution: Pesticides; 2021 Available from: http://www.documents.worldbank.org/curated/ en/689281521218090562/pdf/124345-bri-p153343-publicmarch-22-9-pm-wb-knowledge-pesticides.pdf [Last accessed on 2021 Nov 23].

3. Hanke W, Jurewicz J. The risk of adverse reproductive and developmental disorders due to occupational pesticide exposure: An overview of current epidemiological evidence. Int J Occup Med Environ Health. 2004;17(2):223-43.

PMid:15387079

4. Koureas M, Tsakalof A, Tsatsakis A, Hadjichristodoulou C. Systematic review of biomonitoring studies to determine the association between exposure to organophosphorus and pyrethroid insecticides and human health outcomes. Toxicol Lett. 2012;210(2):155-68. https://doi.org/10.1016/j.toxlet.2011.10.007 PMid:22020228

5. Aryal K, Neupane S, Lohani G, Jørs E, Neupane D, Khanal P, Jha $\mathrm{B}$, et al. Health Effects of Pesticide among Vegetable Farmers and the Adaptation Level of Integrated Pest Management Program in Nepal, 2014; 2016.

6. Sharma DR, Thapa RB, Manandhar HK, Shrestha SM, Pradhan SB. Use of pesticides in Nepal and impacts on human health and environment. J Agric Environ. 2013;13(1):67-74.

7. Hung DZ, Yang HJ, Li YF, Lin CL, Chang SY, Sung FC, et al. The long-term effects of organophosphates poisoning as a risk factor of CVDs: A nationwide population-based cohort study. PloS One. 2015;10(9):e0137632. https://doi.org/10.1371/ journal.pone. 0137632 PMid:26339906

8. Jaga K, Dharmani C. Sources of exposure to and public health implications of organophosphate pesticides. Rev Panam Salud Publica. 2003;14(3):171-85. https://doi.org/10.1590/ s1020-49892003000800004

\section{PMid:14653904}

9. Rosenstock L, Keifer M, Daniell WE, McConnell R, Claypoole K. Chronic central nervous system effects of acute organophosphate pesticide intoxication. The pesticide health effects study group. Lancet. 1991;338(8761):223-7. https://doi. org/10.1016/0140-6736(91)90356-t

PMid:1676786
10. Reform, Pesticides and Human Health; 2020. Available from: https://www.pesticidereform.org/pesticides-human-health [Last accessed on 2020 Nov 23].

11. Lee YK, Hou SW, Lee CC, Hsu CY, Huang YS, Su YC. Increased risk of dementia in patients with mild traumatic brain injury: A nationwide cohort study. PloS One. 2013;8(5):e62422. https:// doi.org/10.1371/journal.pone.0062422.

PMid:23658727

12. Bhandari G, Atreya K, Scheepers PT, Geissen V. Concentration and distribution of pesticide residues in soil: Non-dietary human health risk assessment. Chemosphere. 2020;253:126594.

13. Bempah CK, Buah-Kwofie A, Denutsui D, Asomaning J, Tutu AO Monitoring of pesticide residues in fruits and vegetables and related health risk assessment in Kumasi Metropolis, Ghana. Res J Environ Earth Sci. 2011;3(6):761-71.

14. ATSDR, ATSDR Public Health Assessment Guidance Manual Available from: http://www.atsdr.cdc.gov/hac/phamanual. [Last accessed on 2021 Nov 20].

15. Permentan R. Peraturan Menteri Pertanian Republik Indonesia Nomor 04/Permentan/PP.340/2/2015. Tentang Pengawasan Keamanan Pangan Terhadap Pemasukan Dan Pengeluaran Pangan Segar Asal Tumbuhan; 2015.

16. Sapahin HA, Makahleh A, Saad B. Determination of organophosphorus pesticide residues in vegetables using solid phase micro-extraction coupled with gas chromatographyflame photometric detector. Arab J Chem. 2019;12(8):1934-44.

17. Yao ZW, Jiang GB, Liu JM, Cheng W. Application of solid-phase microextraction for the determination of organophosphorous pesticides in aqueous samples by gas chromatography with flame photometric detector. Talanta. 2001;55(4):807-14. https:// doi.org/10.1016/s0039-9140(01)00504-5 PMid: 18968428

18. Munarso SJ, Broto W. Study of pesticide residue content on cabbage, carrot, and tomato at Malang East Java and Cianjur West Java. 2016;5(1):27-32.

19. Milatovic D, Gupta RC, Aschner M. Anticholinesterase toxicity and oxidative stress. ScientificWorldJournal. 2006;6:295-310. https://doi.org/10.1100/tsw.2006.38

PMid: 16518518

20. Lotti M, Moretto A, Zoppellari R, Dainese R, Rizzuto N, Barusco G. Inhibition of lymphocytic neuropathy target esterase predicts the development of organophosphate-induced delayed polyneuropathy. Arch Toxicol. 1986;59(3):176-9. https://doi. org/10.1007/BF00316329

PMid:2434058 